5. května 2016 Praha

\title{
Děti jsou málo venku, myslí si čeští rodiče
}

\section{Poprvé byl v České republice uskutečněn reprezentativní výzkum, který zkoumá, jak děti ve věku žáků základní školy tráví svůj čas venku a co si o tom myslí jejich rodiče.}

Rozsáhlý výzkum „České děti venku“ provedený na reprezentativním vzorku 1515 českých dětí a stejném počtu jejich rodičů realizovala Nadace Proměny Karla Komárka. Toto šetření jako první svého druhu v České republice ukazuje, že typický český školák tráví venku ve všední den v průměru 1 hodinu a 41 minut a o víkendových dnech v průměru 2 hodiny a 49 minut. Dohromady průměrné dítě stráví venku kolem 14 hodin týdně.

„Tento výsledek může mnoho lidí přijemně překvapit. Je ale důležité, že mezi dětmi jsou v této oblasti velké rozdily a hodně dětí dnes dává před pobytem venku prednost televizním a počítačovým obrazovkám, "říká koordinátorka výzkumu Dagmar Loubalová z Nadace Proměny Karla Komárka. Zatímco 11 \% dětí tráví někde venku méně než 4 hodiny týdně, $10 \%$ dětí je venku více než 26 hodin týdně. Celých 50 \% dětí se ve zkoumaném týdnu nedostalo do prírody.

Výzkum také zjištóval, v jakém venkovním prostředí se děti - v rámci školních i mimoškolních aktivit zdržují. Nejčastěji děti pobývají na zahradě nebo na dvorku (v průměru 4:31 týdně), dále na ulici ( $v$ průměru 3:31 týdně) a na hřišti (v průměru 2:57 týdně). Nejméně času naopak tráví v prírodě ( $v$ průměru 2:03 týdně) a $v$ parku (1:02 týdně). $V$ zeleni tedy $v$ průměru tráví jen něco málo přes polovinu všeho času, který jsou venku.

Koordinátorka výzkumu Dagmar Loubalová k tomu dodává: „Z odpovědí dětských účastníků výzkumu jsme zjistili, že můžeme rozlišit dva základní způsoby, jak české děti chodí ven. Starší děti z rodin s nižším vzděláním, které tráví více času u obrazovek telefonů, počitačů a televizí, pobývaji ve všední dny výrazně více času na ulici. Jejich protikladem jsou děti, které jsou během všedních dnů venku méně, zejména na ulici, ale je pro ně charakteristické trávit výrazně více času v prírodě a další zeleni během víkendů. Častěji se s tímto způsobem pobývání venku setkáme mezi mladšími dětmi z rodin s vyšším vzděláním, které tráví méně času u obrazovek."

Přestože mezi českými dětmi existují velké rozdíly, většina rodičů se shodne na tom, že děti jsou venku málo. Celých 81 \% z nich se domnívá, že děti potřebují být venku každý den, stejně tolik jich pak považuje nedostatek kontaktu s prírodou u dnešních dětí za velký problém a souhlasí s tím, že se tento problém týká také dospělých.

Rodiče si zároveň myslí, že děti tráví př́liš mnoho času u elektronických médií a považují je za největší překážku, která dětem brání být více venku. Na internetu, sledováním televize nebo DVD, hraním počítačových her a poslechem hudby totiž děti ve všední den prủměrně stráví 4 hodiny a 14 minut, což je o více než dvě a půl hodiny více, než kolik času pobývají ve všední dny venku. 
Výzkum také přináší odpověd' na otázku, jaké možnosti trávit čas venku dává dětem školní docházka. Z odpovědí dětí a jejich rodičů vyplývá, že během výuky se ve zkoumaném týdnu dostala ven jen menšina dětí (nejčastěji se jednalo o hřiště, v 8 \% případů). Jen o něco málo lepší byla situace o přestávkách. Přestože většina českých škol má na svém pozemku nebo v těsné blízkosti sportoviště, hřiště, zeleň nebo park, málokterá toho využívá. Dvě třetiny českých rodičů se přitom domnívají, že by školy měly do svého venkovního prostředí více investovat. Ředitelka Nadace Proměny Karla Komárka Jitka Přerovská k tomu říká: „Právě na potenciál venkovního prostředí škol dlouhodobě upozorňujeme naším programem Zahrada hrou. Zaměřujeme se na školní zahrady a snažíme se ukázat, jak mnohostranně se daji využít - nejenom že jsou pro děti príležitostí, jak být více venku, v pohybu a $v$ kontaktu s prírodě blízkým prostředím, ale mohou také obohatit výuku a podporovat všestranný rozvoj dètí, jejich zdraví a kreativitu."

Prostřednictvím programu Zahrada hrou podporuje Nadace Proměny Karla Komárka proměny českých školních zahrad. Od roku 2010 vzniklo 7 nových zahrad a právě probíhá další grantová výzva, ve které může príspěvek na novou zahradu získat dalších 5 škol.

Na výzkumu „České děti venku“ Nadace Proměny Karla Komárka se podílela také výzkumná agentura Median.

Více zde: www.nadace-promeny.cz/cz/vyzkum.html

kontakt:

Petra Hrubošová Jitka Přerovská

+420277006276 +420225010271

+420775654314 jitka.prerovska@nadace-promeny.cz

petra.hrubosova@nadace-promeny.cz

Ilustrační foto: archiv Nadace Proměny Karla Komárka 